\title{
MEMES AND MEDIA'S ROLE IN RADICALIZATION
}

Tina Askanius, Associate Professor in Media Communication Studies - School of Arts and Communication Malmo University, Sweden

Disclaimer: This briefing note contains the encapsulation of views presented by the speaker and does not exclusively represent the views of the Canadian Association for Security and Intelligence Studies.

\section{Key Events}

On September 16, 2021, Dr. Tina Askanius presented on Memes and Media Usage for Radicalization at the 2021 CASIS Vancouver Defence Security Advisory Network Workshop. The key points discussed were memes as cultural units of meaning, their serious global implications, their ability to easily break through cultural and linguistic barriers, and their intricate ability to serve as 'gateways' into more extreme elements of far-right ideologies.

\section{Nature of Discussion}

Dr. Askanius argued that memes have serious global implications as they virally spread due to their ease of creation and dissemination, especially through various cultural and linguistic boundaries. Therefore, Dr. Askanius argues that memes should be a topic of concern, especially for security and intelligence researchers and practitioners, considering their ability to serve as a 'gateway' and to redirect those viewing and sharing this material towards more extremist content and ideologies found throughout both the surface web and dark web.

\section{Background}

Dr. Askanius argued that a mass-following of those attracted by extremist ideologies was triggered by activities such as violent memes, viral murder fantasies, and the banalization of white supremacist violence. She added that the white supremacist memes campaign around the 2018 general elections in Sweden, which, for example, called for the execution of politicians, started with anti-democratic, white Nordic resistant, and national socialist groups. The reach of these memes was strong within Sweden and resonate with and feed into similar campaigns across Scandinavia and other regions within Europe because of their ability to break through cultural and linguistic barriers, using stock photos and easily comprehensible symbols and popular culture references. 
Sweden and its memes movement should concern practitioners and researchers globally. Memes are considered to be 'cultural units of meaning', in that they are developed and spread virally by relating to and intersecting with other memes transnationally. The European Commission's report titled, "It's not funny anymore. Far-right extremists' use of humour" (Fielitz and Ahmed, 2021) references memes as a concern for preventing and countering violent extremism (P/CVE) practitioners. It also discusses how the meme culture established a strong presence through image-based sites like 4chan and 8kun (previously 8 chan), where extremist messages were shared using underlying humor and irony. These messages - short form quotes usually on the foreground of a background image - seem to easily find their way into the mainstream social media, thus posing a challenge for P/CVE practitioners to distinguish between organized and lone-wolf acts of provocation. Consequently, Dr. Askanius argued that P/CVE practitioners should actively engage in researching this area and disseminating their findings before memes can generate a greater negative impact on a global audience.

Given their viral global reach, memes have the ability to create an emotional connection to a target audience using familiar symbols and icons. A critical example is the New Zealand Christchurch Mosque terrorist attack perpetrated by Brenton Tarrant. Dr. Askanius mentioned that before live-streaming his attack, Tarrant released a 74-page manifesto referencing the word "Valhalla"-German word that means 'hall of death' — which was frequently used in various memes that Tarrant had been exposed to. Dr. Askanius further added that such extremist meme propaganda is praised by extreme-right groups for its success in reaching a global audience, which is another component that should concern P/CVE practitioners: memes can blur national boundaries and travel back and forth between fringe and mainstream media.

Finally, Dr. Askanius mentioned that other unique traits of the meme culture is that it is driven by 'swarms' - an internet jargon that refers to a temporal alliance of users - and it exhibits a sense of fluidity that makes it difficult to regulate in a meaningful way. Memes can foster a sense of community and belonging, and by using satire and humour, they allow a target audience to be 'in' on the joke and self-identify with the message of that meme. Although the overarching presence of memes might seem unworthy of attention, Dr. Askanius argued that they ultimately serve as 'gateway drugs' into more extreme elements of far-right ideologies. She also pointed to the fact that many case studies, including terrorist attacks in Germany, El Paso, and Christchurch, indicated that the perpetrators of 
those attacks had no criminal record and emerged from digital subcultures in which memes abound.

\section{Key Points of Discussion}

- Memes are considered to be cultural units of meaning (image, text or audio fragments) that develop and spread virally by copying or combining with other units.

- Memes have serious global implications: although they are created locally, they can spread virally on a global scale because they are easily created and shared through various online platforms.

- Memes can break cultural and linguistic barriers: they utilize stock photos which are easily translated through visual comprehension despite any potential language barriers.

- Memes may not trigger an immediate sense of seriousness and urgency, but they do serve as a 'gateway' into more extreme elements of far-right ideologies.

- It is recommended that researchers and practitioners continue to investigate memes due to their real-world application by perpetrators, such as the Christchurch attacker who referenced memes in his Facebook Live and manifesto.

\section{Critical Thinking Questions}

- Is it more effective and efficient to set guidelines to regulate activities mediated by these tools than to manage/regulate people's thoughts and attitudes?

- Are memes a catalyst or tool used by social movements to create far-right ideological appeal in mainstream circles?

\section{Key Terms}

Cultural Unit of Meaning: The usage of humor, irony, and ambiguity across cultural expressions of neo-Nazism and how ideas, symbols, and layers of meaning travel back and forth between neo-Nazi and Alt-right groups within Sweden (Askanius, 2021, para. 1).

Dark Web: The dark web is a part of the internet that is not indexed by search engines but is accessible via specific URL links. This access point structure through the world wide web portal allows for anonymity and therefore ease of access into both legitimate and illegitimate marketplaces (Guccione, 2021).

The Journal of Intelligence, Conflict, and Warfare

Volume 4, Issue 2 
Memes: bite-sized nuggets of political ideology and culture that are easily digestible. They employ humor and rich intertextuality and are curated for the social media space (Askanius, 2021, para. 2).

Provocation: a spoken, written or acted expression meant to trigger a negative response from the receiver. Individuals may engage in behaviours more closely associated with trolling, deploying transgressive content to assert their in-group identity, or to provoke others (Colley, 2020)

Swedish Memes Movement: The main communication strategy used by the Nordic Resistance Movement with a focus on using hipster emblems and humorous memes (Askanius, 2021, para. 3).

Terrorist Attack: also referred to as "terrorism", a violent, criminal act committed by individuals and/or groups who are inspired by, or associated with, designated terrorist organizations or nations. "International terrorism" refers to activities that involve violent acts or acts dangerous to human life that are in violation of the criminal laws of a country and appear to be intended to coerce or intimidate a civilian population, to influence the policy of a government by intimidation or coercion, or to affect the conduct of a government by, for example, mass destruction, assassination, or kidnapping. International terrorism activities occur primarily outside the territorial jurisdiction of the country or transcend national boundaries in terms of the means by which they are accomplished, the persons they appear intended to intimidate or coerce, or the locale in which their perpetrators operate or seek asylum (United States Government Publishing Office, 2009). "Domestic terrorism" refers to activities that are of the same nature as international terrorism but occur primarily within the territorial jurisdiction of a country (Federal Bureau of Investigation, 2020).

White Nordic Resistance: also referred to as "Nordic Resistance Movement" (NRM), which was formed in 1997 by neo-Nazi nationalists in Sweden, subscribes to a nationalist socialist, or neo-Nazi, ideology that is avowedly antiSemitic, anti-gay, anti-immigrant, pro-white, and pro-Hitler. The NRM thus seeks to regain power from the elite and unite the Nordic states into a Nordic Nation able to assert itself militarily, economically and culturally (Counter Extremism Project, 2021).

White Supremacist: an indivudal that holds the beliefs and ideas purporting natural superiority of the lighter-skinned, or white, human races over other racial groups. In contemporary usage, the term white supremacist has been used to describe some groups espousing ultranationalist, racist, or fascist doctrines. 
White supremacist groups often have relied on violence to achieve their goals (Jenkins, 2005).

\section{Further Readings}

"Do you want meme War?" Understanding the visual memes of the German far right. In M. Fielitz \& N. Thurston, Post-Digital Cultures of the Far Right (pp. 137-154). transcript Verlag (2018) by Lisa Bogerts \&Maik Fielitz https://doi.org/10.14361/9783839446706-010

Explaining the emergence of echo chambers on social media: The role of ideology and extremism (2017) by Jonathan Bright https://papers.ssrn.com/sol3/papers.cfm?abstract_id=2839728

On frogs, monkeys, and execution memes: Exploring the humor-hate nexus at the intersection of neo-Nazi and alt-right movements in Sweden. Television \& New Media, 22(2), 147-165 (2021, January 22) by Tina Askanius https://doi.org/10.1177/1527476420982234 


\section{References}

Askanius, T. (2021, January 22). On frogs, monkeys, and execution memes:

Exploring the humor-hate nexus at the intersection of neo-Nazi and altright movements in Sweden. Television \& New Media, 22(2), 147-165. https://doi.org/10.1177/1527476420982234

Colley, T. (2020, September 20). The challenges of studying 4chan and the AltRight: 'Come on in the water's fine.' New Media \& Society. https://doi.org/10.1177/1461444820948803

Counter Extremism Project. (2021). Nordic resistance movement. https://www.counterextremism.com/supremacy/nordic-resistancemovement

Federal Bureau of Investigation. (2020, November). Domestic terrorism. https://www.fbi.gov/file-repository/fbi-dhs-domestic-terrorismdefinitions-terminology-methodology.pdf/view

Fielitz, M., \& Ahmed, R. (2021). It's not funny anymore. Far-right extremists' use of humour. European Commission. https://ec.europa.eu/homeaffairs/system/files/2021-03/ran_adhoc_pap_fre_humor_20210215_en.pdf

Guccione, D. (2021, July 1). What is the dark web? How to access it and what you'll find. CSO. https://www.csoonline.com/article/3249765/what-isthe-dark-web-how-to-access-it-and-what-youll-find.html

Jenkins, J. P. (2005, March 17). White supremacy. Britannica. https://www.britannica.com/topic/white-supremacy

United States Government Publishing Office. (2009). United States Code. Chapter 113B - Terrorism. https://www.govinfo.gov/content/pkg/USCODE-2009title18/html/USCODE-2009-title18-partI-chap113B-sec2331.html 


\section{(c) $(1) \Theta$}

EY No No This work is licensed under a Creative Commons Attribution-NonCommercial-NoDerivatives 4.0 International License.

(C) (TINA ASKANIUS, 2021)

Published by the Journal of Intelligence, Conflict, and Warfare and Simon Fraser University

Available from: https://jicw.org/ 